\title{
The analysis of earnings management with classification shifting by using discontinued operations in Indonesia
}

\author{
Anthonius \\ Universitas Kristen Maranatha, Bandung, Indonesia \\ Etty Murwaningsari \\ Universitas Trisakti, Jakarta, Indonesia
}

\begin{abstract}
Keywords
Classification shifting, discontinued operations, unexpected core earnings, unexpected change in core earnings, Indonesia
\end{abstract}

\begin{abstract}
This research aims to exam the proven of management in order to do classification shifting by using post discontinued operations. This research uses quantitative data. The data used in this research includes the secondary data that is financial statements of the companies listed on the Indonesian stock exchange from 2013 to 2015. The data analysis used in this research was multiple linear regression with data cross section, which is processed by using SPSS. The findings show that there are positive effects of discontinued operations to unexpected change in core earnings; the management has done classification shifting; in this case, management has done earnings management. The findings signify that there is an indication of classification shifting in the research sample in which the figures contained in financial statements, especially the account of discontinued operations, which is not reliable. The result of this research can be used by the investors as the basis for decision-making, especially investment decisions.
\end{abstract}

Corresponding author: Anthonius

Email addresses for corresponding author: anthony_partners@yahoo.com

First submission received: $26^{\text {th }}$ October 2017

Revised submission received: $9^{\text {th }}$ January 2018

Accepted: 29th January 2018

\section{Introduction}

Financial statements are the information that describes the financial condition of companies. Therefore, financial statement becomes a tool of information from the parties inside and outside the companies. Financial statements for the investors can be the basis for the investment of decision-making. By measuring the benefits of the financial statements importance for the various parties, management can make an opportunity in order to make earnings management in financial statement. Therefore, the financial statement is looked well by the readers, which can eventually attract the investors. Earnings management is the process of taking deliberate steps in limitation of general accounting principles to produce something expected and reported level of profits (Beneish, 2006). This research proves that the companies with aggressive earnings management attract more investors to invest (Yang, Hsu, \& Yang, 2015).

One of the important aspects in financial statement is the profit rate. It becomes the center of attention from the users of financial statements. The profit rate is used as management performance indicators in work. The profit rate is important in order to shows the opportunistic behavior of management to make manipulation towards the profit rate that will be reported in financial statement. Management is motivated to show excellent performance through the profit and the gain value that are earned by the company. Therefore, a company in this case is management, which tends to choose and apply accounting methods that can give better information of the profits.

Talking about earnings management, there is a tool of earnings management that is called classification shifting; it is a method to process the profit by deliberately shifting the classification of items in profit/loss statements (McVay, 2006). 
Classification shifting can be done by shifting operational expenses to transitory accounts like irregular items (expenses down) or shifting profit from transitory accounts like irregular items to operating income (revenue up) that aimed to improve core earnings (profit that is earned from normal company activity) that are reported by the company (McVay, 2006). One of irregular items is a discontinued operation. A discontinued operation is an entity component, either it has been released or classified as it is owned for sale. It represents the line of business or geographic area of separated primary operation, as a part of coordinated single plan to release from line of business or geographic area of separated primary operation or subsidiaries that is obtained, especially for the purpose of resale (IFRS No. 5). Classification shifting often does not becomes the attention of users of financial statement, because they usually focus on core earnings. The classification shifting does not modify net profit. However, the classification shifting just shifts the classification and increasing the reported core earnings.

Since McVay's research (2006), there are many researches of classification shifting, including the research of Fan et al. (2010) that developed McVay's model. However, it is used by putting out accrual variables and adding control variable like return $t$ and return $t+1$, and also using quarterly financial data. The result of Fan et al.'s research (2010) found that the manager more likely did classification shifting in fourth quarter. It also shows that in this fourth quarter, the audit process was focused, with the result that the use of classification shifting was not detected by auditor. Barua et al. (2010) tried to investigate classification shifting by using core earnings and discontinued operations. The result found that the manager behavior that shifted core expense to discontinued operations attempt to increase core earnings. The use of discontinued operation variables is more expected to capture the opportunistic behavior of managers, who do classification shifting. A discontinued operation is used because it is an irregular item, which is not the focus of users of financial statements. The result shows that it gives the opportunity for management to manipulate the profit. Therefore, this research is purposed to exam if management is proven to do classification shifting by using post discontinued operations.

\section{Literature review and hypothesis development Earnings Management}

Earnings management emerges a conflict of interests between management and owner. Management do earnings management for their interests, and the interests can be achieved. Earning management, which is done, tend to be opportunist with the aim of increasing the reported profit rate. So, it can attract the investors and make the management performance looks good. Earning management is an accounting policy, real action, which affects the profit to achieve the specific purpose in reporting the profits that are made by manager (Scott, 2012). Meanwhile, according to Healy and Wahlen (1998), earning management is occurred when management use their own calculation in preparing financial statement and selecting the transactions that can change financial statement. Schipper (1989) said that earnings management is the manager's interference in processing financial statement to the parties outside the company that it is intended to gain personal profit for shareholders and managers. Shareholders will gain the profit if managers use earning management to give private information that is known by manager (Healy and Palepu, 1993).

Earnings management action are motivated by the urge to gain economic profit, which is to reduce tax payable, and to gain psychological profit, which is improving the confidence of managers that are involved (Hepworth, 1953). When a manager, at the first time, began to take the top managerial position, it is found that the research became aggressive in managing the profit over the next few years $(\mathrm{Hu}, 2015)$. According to Scott (2012), there are three factors that can motivate managers to do earnings management, they are bonus scheme motivation, debt covenant motivation, political motivation, motivation to meet investor's earning expectation, and keep reputation, initial public offering motivation.

\section{Classification Shifting}

According to McVay (2006), classification shifting is defined as management deliberately do misclassification from items that is available in profit/loss statements, in his research, it is focused on classification shifting of core expense like cost of production, cost of sales and general and administrative costs to special item. A vertical movement to core expense does not change final profit. However, it can cause overstated core earnings. This classification shifting actually does not change final profit, but it can 
give the impact that is significant to investors and other users of financial statements. Manager tends to do classification shifting in order to evade reporting operational losses in company (Nagar \&Sen, 2017) In his opinion (2006), classification shifting is different with accrual management and manipulation of real economic activity in many cases. First, classification shifting does not change net profit. The users of financial statements often focus on net profit, with the result that this classification shifting can be missed from the attention of users of financial statement. Moreover, classification does not reduce future earnings or past earnings, so that future earnings will be same as actual earnings, whereas both other earning management tools increase expected performances in the future and reduce future earnings or past earnings to increase current earnings.

For instance, from classification shifting through discontinued operations, if it is a retail, which has many stores and one of the stores is closed, so it is inserted into discontinued operations' account, but management allocate a certain amount of advertising costs from stores that are still operating to discontinued operations. This case is done in order to make core earnings increase (Barua et al., 2010).

\section{Discontinued Operation}

Based on IFRS No. 5, discontinued operations are entity components either it has been released or classified as it is owned for sale. It represents line of business or geographic area of separated primary operation, as a part of coordinated single plan to release from line of business or geographic area of separated primary operation or subsidiaries that is obtained especially for the purpose of resale.

According to IFRS No. 5, disclosure of discontinued operations in the amount of comprehensive profit statement consisting of the amount of profit or loss after taxes of discontinued operations, and it recognized in the fair value measure. After deducting the cost for sale or the disposal of assets or disposal group that related to discontinued operations, it is presented in the amount of comprehensive profit statement or in an identifiable section with discontinued operations in a separated part of the continuing operation.

\section{Hypothesis Testing}

Barua et al. (2010) used same methods with McVay (2006) to investigate if manager did classification shifting in order to manage the profit when the company reported discontinued operations. This research uses discontinued operations because there are no previous studies that used discontinued operations for classification shifting. On the other hand, there is an adaptation of SFAS No. 144; it can increase the frequency of reporting discontinued operations. This research is the first research that investigates the implication from the increasing of recognition of discontinued operations for earnings management after SFAS No. 144. The research data that is used from 1989 to 2005 is obtained from Annual Compustat and I/B/E/S Summary Files. It is found that positive effects of discontinued operations towards unexpected core earnings in the company, which suffered losses due to discontinued operations. The amount of classification shifting that used discontinued operations has decreased after SFAS No. 144. This research also puts outaccrual variables from the measuring model of predicted core earnings and evidently the result is still consistent with the previous one.

This research more focuses on classification shifting between core expense and discontinued operations. For answering the first problem formulation, which is if management is proven to do classification shifting by using post discontinued operations, hypothesis 1 and 2 are tested. Hypothesis 1 is aimed to see if there is indication of classification shifting through discontinued operation and to determine if the classification is really occurred, hypothesis 2 is tested.

The use of discontinued operations in this research refers to the previous study that is conducted by Barua et al. (2010 The disclosure of discontinued operation is a part of irregular items that often becomes management discretion. It also often misses from the attention of investors, auditors, and other users of financial statement. Thus, it can provide a gap to management in order to act opportunistic. One of opportunistic behavior of management towards discontinued operation is by doing classification shifting, which is if in that year, the company admits to discontinued operations. Furthermore, the profit and loss from discontinued operations are shifted upward/downward, so there are reported core earnings in company increases For instances, from classification shifting through discontinued operations, a retail that has many stores and one of the stores is closed is inserted into discontinued operations' 
account. However, management do classification shifting with allocating a certain amount of advertising costs from stores that are still operating to a store that is closed on discontinued operations in order to make core earnings increase (Barua et al., 2010).

Barua et al. (2010) said that in addition to increase core earnings, by shifting the operational cost into discontinued operations, it can increase operating earnings and continuing operation earnings. Then, the increasing of three profits can cause stock valuation to more increase to be higher than the increase of core earnings only. Barua et al. (2010) found that there was a positive effect of discontinued operations towards unexpected core earnings that was an indication of the occurrence of classification shifting.

\section{H1: Discontinued operations have a positive effect on unexpected core earnings.}

The increasing of core earnings in company is not only caused by the opportunistic actions of management that do classification shifting, but also from the company that experiences efficiency gains produced by operating activity (McVay 2006). According to Wulandari and Kusuma (2011), if the increase of unexpected core earnings is occurred because of real economic improvement, then the unexpected core earnings in the following year will occur the same increase. However, if the increase is caused by classification shifting, then unexpected core earnings will decrease in the following year, because in the following year, most likely it does not happen again. Classification shifting and core expense that have been shifted in $t$ year will show again in the following year, so that the effect of discontinued operations towards unexpected core earnings in the following year $(t+1)$ will be the opposite compared to $t$ year.

On the other hand, the increase of core earnings also can be caused by the occurrence of classification shifting in $t+1$ and in $t$ year. If the classification shifting is not occurred, then the investor predictions towards reported core earnings in $t+1$ will be incorrect. It is also found that the unexpected core earning $t+1$ is higher than in $t$ year. For ensuring the increasing of core earnings is caused by classification shifting, then the second hypothesis is tested.

H2: Discontinued operations in this year have a negative effect on unexpected change in core earnings in the following year.

\section{Methods}

This research aims to detect earnings management using classification shifting by testing towards discontinued operations and core earnings. The research model is shown in Figure: Research model

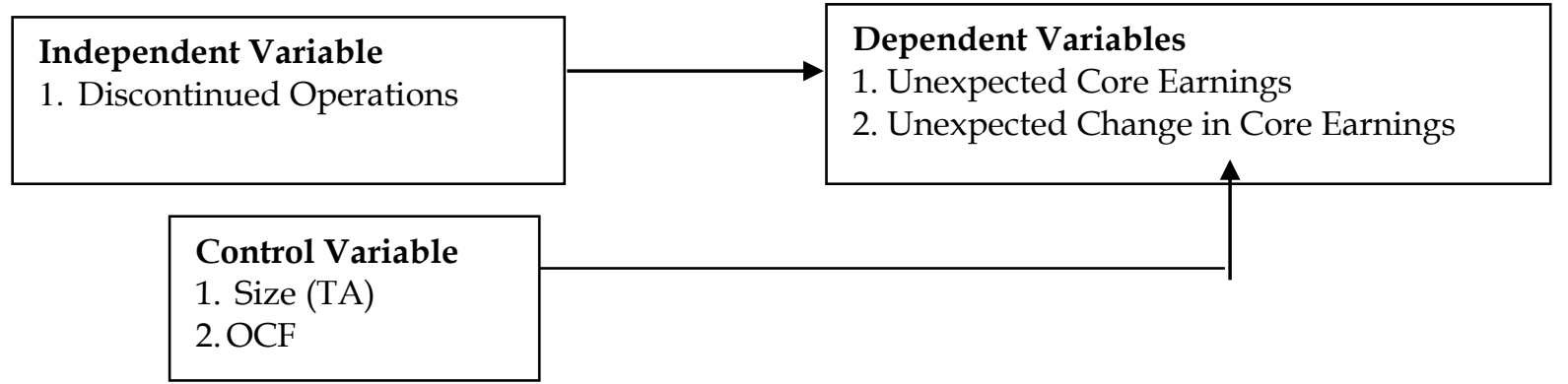

Figure 1: Research model

Variables that is used in this research, including discontinued operations variable as independent variable, unexpected core earnings and unexpected change in core earnings variables as dependent variable, control variable, including company size and operating cash flow. This research used data in Indonesia. The population of this research is the company that is listed in Indonesia stock exchange from 2013 to 2015. This research used quantitative data and data resource that is used was secondary data, which is financial statement the company that is listed in Indonesia stock exchange from 2013 to 2015. The method of data analysis that is used in this research was multiple linear regression with data cross section, which processed by using SPSS. Before doing regression test, there is a test conducted on a violation of assumptions that can be occurred on regression model, which is multicollinearity, heteroscedasticity, and autocorrelation (Nachrowi and Usman, 2006). 


\section{Operationalization of Variables \\ Dependent Variable}

a. Unexpected Core Earnings

Unexpected core earnings (UE_CEt) are the distinction between reported core earnings and predicted core earnings.

$U E_{-} C E_{t}=$ reported $C E_{t}-$ predicted $C E_{t}$

Reported $\mathrm{CE}_{\mathrm{t}}$ is reported core earnings in profit statement in $t$ period, which is calculated from sale - cost of production - selling expenses, general expenses \& administration

Predicted $\mathrm{CE}_{\mathrm{t}} \mathrm{is}$ predictedcore earnings in $t$ year in which the prediction value is calculated by using predicted value of equation (1) that estimated based on the year and industries (McVay, 2006).

$\mathrm{CE}_{\mathrm{i}}=\mathrm{a}_{0}+\mathrm{a}_{1} \mathrm{CE}_{\mathrm{it}-1}+\mathrm{a}_{2} \mathrm{ATO}_{\mathrm{i}}+\mathrm{a}_{3}$ ACCRUALS $_{\mathrm{it}-1}+\mathrm{a}_{4}$ ACCRUALS $_{\mathrm{i}}+\mathrm{a}_{5} \Delta$ SALES $_{\mathrm{i}}+\mathrm{a}_{6}$ NEG_ASALES $_{\mathrm{i}}+$ $\varepsilon_{\text {i. }}$

Notes:

$\mathrm{CE}_{\mathrm{i}} \quad=$ Core Earnings (Sale - Cost of Production - Administration and Sales Fee that is divided by sales on $t$ period) $i$ company

$\mathrm{CE}_{\mathrm{it}-1} \quad=$ Core Earningsi companyt-1period

$\mathrm{ATO}_{\mathrm{i}} \quad=$ Asset Turnover Ratioi company

ACCRUALS $_{\text {it-1 }}=$ Operating Accrualsicompanyt-1 period

(Net profit before extraordinary posts - Cash flow from operation divided by sales on $t$ period)

ACCRUALS $_{\mathrm{i}}=$ Operating Accrualsi company

$\triangle$ SALES $_{\mathrm{i}} \quad=$ Percentage of Sales Change $i$ company

$\left(\right.$ Sales $_{\mathrm{t}}-$ Sales $_{\mathrm{t}-1} /$ Sales $\left._{\mathrm{t}-1}\right)$

NEG_ASALES ${ }_{i}=$ Variabel dummy, which is 1 if $\triangle S A L E S_{t}<0$ or 0 to the contrary

Equation (1) uses the model that is developed by McVay (2006) and also used by the research that conducted by Baruaet al. (2010).

\section{b. Unexpected Change in Core Earnings}

Unexpected change in core earnings ( $\left.\mathrm{UE}_{-} \Delta \mathrm{CE}_{t+1}\right)$ are the distinction between reported change in core earnings year to $t+1$ year and predicted change in core earnings $t$ year to $t+1$ year.

UE_ $\Delta C E_{t+1}=$ reported $\Delta C E_{t+1}-$ predicted $\Delta C E_{t+1}$

Reported $\Delta \mathrm{CE}_{\mathrm{i}}$ is the change of reported core earningsin icompany from tyear tot +1 year (reported $\mathrm{CE}_{\mathrm{t}+1}-$ reported $\left.C E_{i}\right)$

Predicted $\Delta \mathrm{CE}_{\mathrm{i}}$ is the change of predicted core earnings in $i$-company from $t$ year tot+1year, which calculated by using predicted value of equation (2) that taken from the equation of McVay (2006). Equation (2) is used to test $t+1$ year.

$\Delta \mathrm{CE}_{\mathrm{i}}=\beta_{0}+\beta_{1} \mathrm{CE}_{\mathrm{it}-1}+\beta_{2} \Delta \mathrm{CE}_{\mathrm{it}-1}+\beta_{3} \Delta \mathrm{ATO}_{\mathrm{i}}+\beta_{4}$ ACCRUALS $_{\mathrm{it}-1}+\beta_{5}$ ACCRUALS $_{\mathrm{i}}+\beta_{6} \Delta$ SALES $_{\mathrm{i}}+\beta_{7}$ NEG_ASALES ${ }_{i}+\gamma_{i}$.

Equation (2) uses model that developed by McVay (2006), which was also used in the research that was conducted by Barua et al. (2010). $\mathrm{CE}_{\mathrm{t}-1}$ and $\Delta \mathrm{CE}_{\mathrm{t}-1}$ variables are used to see how far the inverse relationship with core earnings in the past year.

\section{Independent Variable}

Discontinued Operations $\left(\mathrm{Do}_{\mathrm{i}}\right)$ :

It is scaled by sales and multiplied by -1 to capture the positive relationship between discontinued operations with unexpected core earnings.

$\mathrm{DO}_{i}=$ Discontinued Operations $_{i}{ }^{*}(-1) /$ Sales 


\section{Control Variable}

The research used some characteristics of the company (Baruaet al., 2010), they are company size $\left(\mathrm{SIZE}_{\mathrm{i}}\right)$ and operating cash flow $\left(\mathrm{OCF}_{\mathrm{i}}\right)$. Company size as proxy of political costs is considered very sensitive to earnings reporting behavior (Watts and Zimmerman, 1990). The result of this research about company size shows that company size materially affects earnings management techniques (Noronha, Zeng, Vinten, Noronha, \&Zeng, 2009). Companies of public ownership have strong incentive. On the other hand, the big companies are more appreciated by the market, because it is considered that they have better operational control and adequate understanding of the business, so the companies are expected to be able to maintain their credibility in the market (Rahmani and Akbari, 2013)

Operating Cash Flow (OCFi), calculated from cash flow from operations with total assets $t-1$, OCF is one of proxies of the company's performance except the profit, investors give more attention to OCF, because OCF is considered more 'real' rather than the profit. In this research, OCF is use as control variable to control the possibility of earnings management through manipulations of the real activity.

\section{Testing Hypothesis 1}

To see classification shifting through discontinued operations in this year towards unexpected earnings in this year. A test is conducted by using the equation that is used by Barua et al. (2010), which is presented in the equation (3).

UE_CE ${ }_{i}=\varphi_{0}+\varphi_{1} \mathrm{DO}_{\mathrm{i}}+\varphi_{2} \mathrm{SIZE}_{\mathrm{i}}+\varphi_{3} \mathrm{OCF}_{\mathrm{i}}+\varepsilon_{\mathrm{i}}$

Notes:

$\mathrm{UE} \_\mathrm{CE}_{\mathrm{i}}=$ Unexpected core earningsi company

$\mathrm{DO}_{\mathrm{i}} \quad=$ Discontinued operations $i$ company

$\mathrm{SIZE}_{\mathrm{i}} \quad=$ Company size $i$

$\mathrm{OCF}_{\mathrm{i}} \quad$ Operating Cash Flow $i$ company

In this research, $\varphi_{1}$ and $\varphi_{2}$ are predicted to have a positive sign (+). It can be interpreted that there is the indication of earnings management's behavior through that can be seen from the positive effect of discontinued operations to unexpected core earnings. To prove that it is right the increasing of unexpected core earnings is caused by the occurrence of classification shifting, and then it is conducted the second hypothesis test.

\section{Testing Hypothesis 2}

To see the negative effect of discontinued operations in this year to unexpected change core earnings in the following year. A test is conducted by using the equation that is used by Barua et al. (2010), which is presented in the equation (4)

$\mathrm{UE} \_\Delta C E_{\mathrm{it}+1}=\eta_{0}+\eta_{1} \mathrm{DO}_{\mathrm{i}}+\eta_{2} \mathrm{SIZE}_{\mathrm{i}}+\eta_{3} \mathrm{OCF}_{\mathrm{i}}+\varepsilon_{\mathrm{it}+1}$

Keterangan:

UE_ $\Delta \mathrm{CE}_{\mathrm{t}+1} \quad=$ Unexpected change in core earningsi companyt+1 year

In this research, $\eta_{1}$ and $\eta_{2}$ are predicted to have a negative sign (-) which can be interpreted that there is a behavior of earnings management through classification shifting by seeing the negative effect of discontinued operations t year to unexpected change in core earnings.

\section{The result and discussion}

The results of examining by using SPSS are as follows:

In testing hypothesis 1 , by using $\mathrm{UE}_{-} \mathrm{CE}_{\mathrm{i}}=\varphi_{0}+\varphi_{1} \mathrm{DO}_{\mathrm{i}}+\varphi_{2} \mathrm{SIZE}_{\mathrm{i}}+\varphi_{3} \mathrm{OCF}_{\mathrm{i}}+\varepsilon_{\mathrm{i}}$, model, the result is as follows: 


\section{Descriptive Statistics}

\begin{tabular}{lccc}
\hline \multicolumn{5}{c}{ Table 1: Descriptive Statistics model 1 } & & \\
\hline & Mean & Std. Deviation & $\mathrm{N}$ \\
\hline UE_CE & $5.8235 \mathrm{E} 8$ & $1.63945 \mathrm{E} 9$ & 63 \\
$\mathrm{DO}$ & $1.0410 \mathrm{E} 7$ & $8.01340 \mathrm{E} 7$ & 63 \\
SIZE $^{*}$ & 9.2831 & 1.38354 & 63 \\
$\mathrm{OCF}^{*}$ & $9.969943 \mathrm{E} 0$ & 58.1283917 & 63
\end{tabular}

Note: UE_CE: Unexpected core earnings, DO: discontinued operations, SIZE: firm's size, OCF: operating cash flow, ${ }^{*}$ in billions rupiah

The result of hypothesis 1

Table 2.The positive effect of discontinued operations towards unexpected core earnings

\begin{tabular}{|c|c|c|c|c|}
\hline \multirow[t]{2}{*}{ Variables } & \multirow[t]{2}{*}{ prediction } & \multicolumn{3}{|c|}{$\begin{array}{l}\text { the positive effect of discontinued operations } \\
\text { towards unexpected core earnings }\end{array}$} \\
\hline & & Coefficients & $t$-value & Beta \\
\hline C & & $0.000^{* * *}$ & $-9,851$ & $-5715502107,85$ \\
\hline DO & + & $0.000^{\star * *}$ & 12.357 & 13,22491293 \\
\hline SIZE & & $0.000^{* * *}$ & 10.751 & 666255823,3 \\
\hline OCF & & $0.095^{*}$ & -1.696 & $-2479745,09$ \\
\hline Adj R2 & & 0,57847222 & & \\
\hline F-statistic & & 104.429 & & \\
\hline Prob (F-statistic) & & $0.000^{*+* *}$ & & \\
\hline Observation & & 63 & & \\
\hline
\end{tabular}

*** Significant at level of 1 percent , ,** Significant at level of 5 percent , * Significant at level of 10 persent Note: DO: discontinued operations, SIZE: firm's size, OCF: operating cash flow

This research proves that the model in the equation 1 has passed the test, because the significant value of Anova table gives a significant value of $0.000<0.05$ and the result of the research also proves that the discontinues operations gives effect to the unexpected core earnings of $57,8 \%$. The result of the research also shows that the classical assumption test has fulfilled the criteria, normality test in testing hypothesis 1 by using one-sample of Kolmogorov-Smirnov test, which is resulted a number of 0,143. It means that the Kolmogorov-Smirnov test is greater than $a=5 \%$ in which it proves that the data is distributed normally. Meanwhile, for heteroscedasticity test, every variable gives a number DO of 0,276, size 0,245 , and OCF 0,428 . It means that the heteroscedasticity test is greater than $a=5 \%$ in which it proves that the data is free of heteroscedasticity. For the multicolinearity test by using collinearity diagnostics, it can be concluded that the data is free of multicolinearity.

The result of regression in the equation model has the equation value of $\mathrm{Y}=-5715502107,85539+$ 13,2249129276075 XI $+666255823,349537$ X2 $-2479745,09379114$ X3 $+\varepsilon$. The testing hypothesis 1 proves that discontinued operations has the significant value of $0.000<$ Alpha $(5 \%)$ and has the $t$ value, which is marked positive $(+)$, of 12.357. It means that there is an indication of earnings management's behavior through classification shifting that is seen from the positive effect of discontinued operation to unexpected core earnings. Thus, the second hypothesis test can be conducted by the occurrences of classification shifting.

\section{The result of Hypothesis 2}

In testing hypothesis 2 , by using UE_ $\Delta \mathrm{CE}_{\mathrm{it}+1}=\eta_{0}+\eta_{1} \mathrm{DO}_{\mathrm{i}}+\eta_{2} \mathrm{SIZE}_{\mathrm{i}}+\eta_{3} \mathrm{OCF}_{\mathrm{i}}+\varepsilon_{\mathrm{it}+1 . .}$ model, the result is as follows: 


\section{Descriptive Statistics}

\begin{tabular}{lccc}
\hline \multicolumn{5}{c}{ Tabel3: Descriptive Statistics model 2 } & & \\
\hline UE_ $\Delta$ CE & Mean & Std. Deviation & N \\
DO & $-24071878,7619$ & $4,98392 \mathrm{E} 8$ & 63 \\
SIZE & 10409735,5079 & 80133994,83778 & 63 \\
OCF & 9,2831 & 1,38354 & 63 \\
\end{tabular}

Table 4. The negative effect of discontinued operations towards unexpected core earnings UE_ $\Delta C E_{i t+1}=\eta_{0}+\eta_{1} D_{i}+\eta_{2} S I Z E_{i}+\eta_{3} O_{C C F}+\varepsilon_{i t+1}$

\begin{tabular}{lccc}
\multicolumn{1}{c}{ Variables } & prediction & the negative effect of discontinued operations towards unexpected \\
core earnings
\end{tabular}

*** Significant at level of 1 percent , ,** Significant at level of 5 percent , ${ }^{*}$ Significant at level of 10 persent Note: DO: discontinued operations, SIZE: firm's size, OCF: operating cash flow

This research proves that the model in the equation 2 has passed the test, because the significant value of Anova table gives a significant value of $0.000<0.05$ and the result of the research also proves that discontinues operations gives effect to unexpected core earnings of 20,87. The result of the research also shows that the classical assumption test has fulfilled the criteria, normality test in testing hypothesis 2 by using one-sample of Kolmogorov-Smirnov test, which resulting a number of 0,111. It means that the Kolmogorov-Smirnov test is greater than $\alpha=5 \%$ in which it proves that the data is distributed normally. For heteroscedasticity test, every variable gives a number DO of 0,489 , size 0,804 , and OCF 0,898 . It means that the heteroscedasticity test is greater than $a=5 \%$ in which it proves that the data is free of heteroscedasticity. For the multicolinearity test by using collinearity diagnostics, it can be concluded that data is free of multicolinearity.

The increasing of the company's core earnings is not only caused by the opportunistic actions of management that do classification shifting, but it can also be caused by the company that occurs efficiency gains, which is generated from operating activity (McVay, 2006). For ensuring that the increase of core earnings is caused by classification shifting, then the second hypothesis test is conducted. Hypothesis 2 claimed that discontinued operations in this year have a negative effect on unexpected change in core earnings in the following year. The result of regression in the equation model has the equation value of $Y$ $=1366719999,20855-1,54558111997326$ X1 + 144371865,871327 X2 + 1857813,47067107 X3. The testing hypothesis 2 proves that the discontinued operations has the significant value of $0.034<$ Alpha (5\%) and has the $t$ value, which is marked negative (-), of 2,177. It implies that there is an earnings management behavior through classification shifting, which is seen from the negative effect of discontinued operation $t$ year to unexpected change in core earnings.

\section{Conclusion}

The result of this research provides the evidence that there are positive effect of discontinued operation towards the unexpected core earnings and the negative effect of discontinued operation towards unexpected change in core earnings; it implies that by using data analysis for three years from 2013 to 2015 towards 63 companies and analyzing the data to the formula that is determined, it was found that in 2014, it was proved that management had done classification shifting, in this case management had 
done earnings management. If unexpected core earnings increased, then there was a possibility that manager opportunistically shifted core expenses (cost of production, cost of sales, and general and administrative costs) to discontinued operations, this is related to the research that conducted by Barua, et al (2010).

If the increase of unexpected core earnings is occurred because of real economic improvement, the unexpected core earnings in the following year will occur the same increase. However, if the increase is caused by classification shifting, the unexpected core earnings will decrease in the following year, because in the following year, it most likely does not happen again. Classification shifting and core expense that have been shifted onto discontinued operations in $t$ year will show again in $t+1$ year. The result of hypothesis test strengthens the result of testing hypothesis 1 in which there was an earnings management through classification shifting by shifting core expense to discontinued operations.

This research has limitation in which this research only used data from 63 companies as sample research. The further researches are expected to be able to enhance the research sample in order to give more precise results.

This research is able to describe that there is an indication of classification shifting, which is occurred on the research sample. The result shows that the figures contained in financial statement, particularly the account of discontinued operations, can be said not reliable. Furthermore, the result of this research can be used by the investors as the basis for decision-making, especially in investment decision.

This research also tries to contribute in the future, and hopefully the future can enrich the sample more, such as big company in ASEAN or even Asia.

\section{References}

Barua, A., Lin, S., \& Sbaraglia, A.M. (2010). Earnings Management Using Discontinued Operations.The Accounting Review. Vol. 85 No.5 Page 1485-1509.

Beneish, M. D. (2006). Earnings Management : A Perspective.Managerial Finance, Vol. 27 Issue: 12, pp.3-17.

Fan, Y., Barua, A., Cready, W.M., \& Thomas, W.B. (2010). Managing Earnings Using Classification Shifting: Evidence from Quarterly Special Items.The Accounting Review.Vol. 85 No. 4 Page.1303-1323.

Healy, P.M. \& Palepu, K.G. (1993). The Effect of Firm's Financial Disclosure Strategies on Stock Price. Accounting Horizon. Vol. 7 No. 1 Page 1-11.

Healy, P.M. \& Wahlen, J.M. (1999). A Review of The Earnings Management Literature and Its Implications For Standard Setting. Vol.13 No.4 Page.365-383.

Hepworth, S.R. (1953). Smoothing Periodic Income. Accounting Review. Page 32-39.

Hu,N., QianHao, Ling Liu, Lee J. Yao. (2015). Managerial tenure and earnings management, International Journal of Accounting \& Information Management, Vol. 23 Issue: 1, pp.42-59.

International Financial Reporting Standard No.5.Non-Current Asset Held for Sale and Discontinued Operations.International Accounting Standard Board.

McVay, S.E. (2006). Earnings Management Using Classification Shifting: An Examination of Core Earnings and Special Items. The Accounting Review. Vol. 81 No.3 Page 501-531.

Nachrowi, D.N.\& Usman, H. (2006). Pendekatan Populerdan Praktis Ekonometrikauntuk Analisis Ekonomidan Keuangan. Lembaga Penerbit Fakultas Ekonomi Universitas Indonesia.

Nagar, N., \&Sen, K. (2017). Classification Shifting: Impact of Firm Life Cycle.Journal of Financial Reporting and Accounting, Vol. 15 Issue: 2.

Noronha, C., Zeng, Y., Vinten, G., Noronha, C., \&Zeng, Y. (2009). Earnings management in China: an exploratory study. Managerial Auditing Journal, Vol. 23 Issue: 4, pp.367-385.

Rahmani, S., \& Akbari, M.A. (2013). Impact of Firm Size and Capital Structure on Earnings Management. Worlds of Sciences Journal. Vol. 01 No. 17 Page 59-71.

Schipper, K. (1989). Commentary on Earnings Management. Accounting Horizons.Vol. 3 No. 4 Page.91-102.

Scott, William R. (2012). Financial Accounting Theory. Second edition. Canada: Prentice Hall.

Watts, R.L., dan Zimmerman, J.L. (1990). Positive Accounting Theory: A Ten-Year Perspective. The Accounting Review.

Wulandari, S., \&Kusuma, I.S. (2011). Mendeteksi Managemen Labadengan menggunakan Classification Shifting: Pengujian Core Earnings dan Extraordinary Items (StudiEmpiris di Negara-Negara ASEAN). Simposium Nasional Akuntansi XIV Aceh.

Yang, W., Hsu, J., \& Yang, T. (2015). Earnings management, institutional shareholdings, and performance of SEO firms. Managerial Finance, Vol. 39 Issue: 6, pp.528-549. 